\title{
The world economy will need even more globalization in the post-pandemic 2021 decade
}

\section{Farok J. Contractor}

Management and Global Business Department, Rutgers Business School, Rutgers University, 1 Washington Park, Newark, NJ 07102, USA

\section{Correspondence:}

FJ Contractor, Management and Global Business Department, Rutgers Business School, Rutgers University, 1 Washington Park, Newark, NJ 07102, USA

e-mail: farok@business.rutgers.edu
Received: 9 September 2020

Accepted: 27 October 2020

Online publication date: 1 February 2021

\begin{abstract}
Instead of the dire predictions of a post-pandemic world characterized by increased global risks, decoupling of economies, shake-up of global value chains, and the retreat of globalization, this article proposes that the changes induced by heightened nationalism and protectionism will be marginal rather than fundamental in nature. These marginally higher risks can easily be handled and ameliorated by multinational enterprises through alternate cross-border business strategies and emerging technologies. Moreover, the paper gives reasons why the future world economy will need even more globalization.

Journal of International Business Studies (2022) 53, |56-|7|.

https://doi.org/ I0.1057/s4I267-020-00394-y
\end{abstract}

Keywords: globalization; global supply chain strategies; risk and risk exposure; decoupling; US-China relationship; contributions of multinational enterprises

\section{INTRODUCTION}

Much has been written about how the global economy will change as a result of the Covid-19 pandemic, including the operations of multinational enterprises (MNEs), and patterns of trade (e.g., Baldwin \& Tomiura, 2020). Particular attention has been focused on the reconfiguration of international supply chains (e.g., Ivanov \& Dolgui, 2020; Verbeke, 2020) since it was reported, early in the pandemic, that $94 \%$ of the Fortune 1000 companies were encountering coronavirus supply chain disruptions (Sherman, 2020). The importance and complexity of cross-border supply or value chains may be gauged from an UNCTAD report that estimated that $60 \%$ of global trade consisted of intermediate goods and services (i.e., components and semi-finished items), with around a quarter recrossing borders at least twice before final assembly or release as a finished product, software or service package (UNCTAD, 2013).

In a post-pandemic world, it is proposed that a fundamental shift in MNE strategies and managerial thinking will occur and will be skewed towards greater risk aversion, nationalism, and protectionism (Fontaine, 2020), pre-existing trends that they say the pandemic has now precipitated. Some go even further, presaging a "legitimacy crisis" for the post-war neoliberal economic order 
(Abdelal, 2020). Others even proclaim the coming "end of globalization" (Young, 2020).

This article instead proposes that the fundamental rationales for globalization have not eroded, and that, in a post-pandemic world, there will be an even greater need and utility for globalization. Certainly, the shifts proposed, such as rethinking of global value chain overdependence, have already begun to occur. However, I argue here that these shifts will be marginal rather than fundamental, and that the basic efficiency, comparative advantage, and rationalization arguments for global investment and trade will remain irresistible, even in a post-Covid-19 world.

\section{HOW THIS PAPER IS ORGANIZED}

It would first be useful to outline how globalization has multiple dimensions measured by scholars and consultancies, in order to frame the argument. Next, the paper will review the fundamental rationales or justification for international business, while recognizing its occasional negative externalities. ${ }^{1}$ The following sections will argue that changes in the organization and configuration of multinational operations, in response to external factors such as rising nationalism and risk-aversion, will be marginal rather than fundamental. The concluding section will highlight why the world will need even more globalization and cross-border collaboration in the future.

\section{MEASUREMENTS FOR GLOBALIZATION}

International Business scholarship is about tracking cross-border movements. The most common measures include traded goods and services, and foreign direct investment (FDI) flows in and out of nations. Data on these are easily found in sources such as the World Investment Report (2020), the World Bank, and OECD. Critics decry the stagnation of the value of FDI and trade measured in current dollars in the post-2008 period, but this belies the fact that the 2008-2019 numbers averaged as much as ten times their 1990 levels. $^{2}$ Some scholars, from a short-term perspective focusing only on the post2008 period, have taken an excessively pessimistic view, ignoring the fact that most FDI and trade indicators, taken over a long-term trend line, i.e., the 1990s-2020 period, show a five- to ten-fold growth (Witt, 2019).

To these as globalization indicators, Verbeke, Coeurderoy and Matt (2018) add cross-border movements of ideas, people, technology, portfolio capital, and "effective institutional practices" by which they imply that multinational companies are the catalysts and conduits of higher standards and practices in the nations in which they invest. Using different data points, the DHL Global Connectedness Index (Altman \& Bastian, 2019) paints a rosier picture over the 2001-2018 period, with information flows (bandwidth, telephone, and printed publications) shown as growing by $76 \%$, people flows (migrants, tourists and foreign students) growing at 20\%, and the FDI Stock/GDP ratio showing an increase of 16 percentage points (or $71 \%$ in terms of percentage growth) from 2001 to 2018). The DHL index shows no growth after 2001 in the geographical breadth coverage of multinational enterprises, echoing Rugman and Verbeke's (2004) assertion that most MNEs limit themselves to a regional coverage. However, Rosa, Gugler and Verbeke (2004) calculated an increased global coverage from the Fortune Global 500 list for $2017^{3}$, stating that “...many large firms are still home-region oriented, but to a lesser extent than before."

Another significant globalization indicator, almost totally ignored by international business scholars, is the cross-border payments (mainly royalties) for the licensing of intellectual property, which increased from US\$26.74 billion (current dollars) in 1990 to $\$ 397.23$ billion in $2019 .{ }^{4}$ Apart from their dramatic growth, international licensing is far less affected by recessions and pandemics, ${ }^{5}$ and is likely to continue its fast growth in the knowledge economy of the future. The royalty numbers seem small in absolute terms, until one probes their strategic significance to global commerce and economics. Foreign sales by licensees at least partially substitute for exports or FDI affiliate sales. How do the sales of these three international business strategies compare? Royalty rates range from $2 \%$ or less for some music and publications to over $8 \%$ for valuable technologies and medicines, so that dividing $\$ 397.23$ by the 0.08 or 0.02 royalty rates yields estimates of licensee sales (achieved by international licensing of intellectual assets) of $\$ 4965$ billion to $\$ 19,862$ billion, respectively. ${ }^{6}$ (Notice that the latter number is comparable to the 2019 world merchandise export sales total).

That MNEs are instruments or channels for the upgrading of institutional standards by foreign host governments is documented in studies such as Jude and Levieuge (2015). The Contractor, Dangol, Nuruzzaman, and Raghunath (2020) study covering 
189 nations shows that better institutional quality attracts larger FDI inflows. The "demonstration effect" of MNEs, in upgrading productivity, sustainability, and environmental and labor standards has been well documented for 45 years (e.g., Caves, 1974 or Moran, Graham \& Blomstron, 2005). ${ }^{7}$ Also, in recent years, the knowledge spillover effects (intended as well as inadvertent) diffusing into the host nation in which the MNE operates have drawn increased attention (Contractor, 2019; Prud'homme, 2019).

Starting in February 2020, unsurprisingly, most measures of globalization declined. However, the fundamental rationales for international business remain unassailable and even more valid in the post-pandemic period.

\section{THE CONTINUING RATIONALES OF INTERNATIONAL BUSINESS}

The inescapable fact is that, into the long future, the world will remain fragmented (into nation states) and unequal (in terms of income, culture, laws, institutions, and business practices). Therein lies the fundamental rationale for international business, which will persist in the post-pandemic period, since inequalities and fragmentation will continue to create aggregation and arbitrage opportunities for MNEs, and for traders and alliances (Ghemawat, 2007). This cross-border "bridging" function performed by international firms will continue to benefit not only them, but also the citizens and companies in host nations to which better managerial, productivity, technological and institutional practices are "demonstrated" (Caves, 1974; Swenson \& Chen, 2014). Consumers in both home and host nations benefit from improved methods and organization, and from heightened competition that results in better quality and design, at lower prices. ${ }^{8}$ Such fundamental justifications for international business will not diminish but may even increase in the future (as discussed in a later section).

Global Production Scale Economies: Combining demand from several markets to achieve economies of production scale is a core argument of International Business theory (Chandler \& Hikino, 2009; Dunning, 2015; Cantwell, 2015). This is especially pertinent when one considers that the vast majority of national markets are small. Among the 20 biggest markets, going downward we quickly have, at ranks 18 and 20, respectively, Saudi Arabia and Turkey, whose GDP is a mere $0.8 \%$ each of global total GDP. Below rank 50, we have not only tiny but also politically risky nations. The bottom 174 countries put together comprise only $19.3 \%$ of the world economy - a highly skewed distribution indeed. Of course, aggregating standardized demand across nations to achieve scale economies is not always easy. For one thing, there is the contrary pull of local adaptation as a marketing strategy. Katsikeas, Samiee and Theodosiou (2006) identify inhibiting factors, such as varying customs and traditions, customer characteristics, stage of product life cycle, regulations, technology, and intensity of competition. Their study shows, however, that, when these barriers are overcome and standardization enables scale economies, this does result in superior performance. The skewed distribution of national economic size and inequality will continue to justify the existence of MNEs.

Global Amortization Scale: Most of the costs of a multinational company are not at the factory but in central organizational and $R \& D$ overheads. Generally, MNEs exhibit a greater technology intensity and spend more on R\&D than comparable domestic firms. Innovations initially have a local root and most R\&D is still carried out in the home nation of the firm. However, the technological and other overheads incurred in the MNE's home country, if spread over many foreign affiliates and markets, reduce the overhead burden (and hence cost) per unit of final production - a luxury that domestic competitors cannot replicate. ${ }^{9}$ As economies become more technology-intensive in the future, this attribute of multinational companies will become even more strategically relevant. ${ }^{10}$

Specialization and Global Value Chain (GVC) Orchestration: Since February 2020, when the pandemic began, much attention has been focused on the coming need to deepen cross-border integration of global value chains, i.e., to make them more resilient (e.g., Verbeke, 2020).The reasoning is that unexpected shocks, such as pandemics, rising nationalism, geo-political frictions, and protectionism, can adversely affect GVCs, which can delay vital supplies, and in the worst case create "stockouts" and shortages (Ivanov \& Dolgui, 2020; Sherman, 2020). In brief, the hypothesis is that the design or orchestration of GVCs in the future will exhibit greater risk-aversion (Aylor et al., 2020), although, undoubtedly, this will vary depending on the sector in question.

This coming "resilience" of supply chains will be manifested in four ways, (1) an increase in the number of suppliers for the same component or 
item (or lower likelihood of reliance on one solesource foreign supplier), (2) geographical diversification of supply sources to more than one country, (3) propinquity of supply sources, in terms of both geographical and political "distance", and (4) Increase in inventory levels at the point of use all of which represent an increase in cost per unit.

However, I argue that this future shift will only be marginal and not fundamental. For one thing, as Miroudot (2020) argues, past experiences show how quickly supply chains recover from disruptions, in some cases more than making up for the business lost during the supply interruption. However, in a longer-term sense, the overarching fact remains that much of international business relies on price-based competitiveness. The strategic imperatives of efficiency or cost-reduction, through the "fine-slicing" of a company's value chain, the dis-internalization (outsourcing) of many of the "slices", and their dispersion internationally (offshoring), will remain a powerful, inescapable competitive mandate (Contractor et al., 2010). This will limit the coming reconfiguration of GVCs to only a marginal or slight shift. As illustrated in Figure 1, the vertical axis tracks "Cost Per Unit of Procured Item" as well as the company's "Risk", while the horizontal axis tracks increasing "Resilience" of a GVC (a composite index constructed from four sub-indicators.

Figure 1 is a representation of the trade-offs calculated by an MNC before and after the pandemic period. That is to say, the Figure 1 framework enables a company to assess whether it should reconfigure its GVC to make it more riskresistant and resilient (or not). "Resilience" of the GVC increases along the horizontal axis based on four strategic components to be decided by the firm:

(i) Number of suppliers worldwide for the item,

(ii) Geographical diversification (number of distinct source countries),

(iii) Propinquity: weighted average of the political and geographic distance from supply sources to the point of assembly or demand, and

(iv) Overall inventory levels.

The cost per unit procured is a J-curve, I hypothesize. ${ }^{11}$ Often, a sole-supplier (being a quasi-monopoly) charges a higher cost per unit than a situation where competitive pressures between two or more suppliers reduces the cost. However, beyond two or three suppliers, the cost per unit is likely to increase simply because the multiplicity of supply sources increases (1) global logistics cost and (2) transaction costs (Berghuis, \& den Butter, 2017).

Risk reduces from left to right in the graph. Resilience of the GVC increases towards the right of the $x$-axis, which reduces supply chain risk - as sources are diversified to more countries, as the weighted average distance from sources to demand

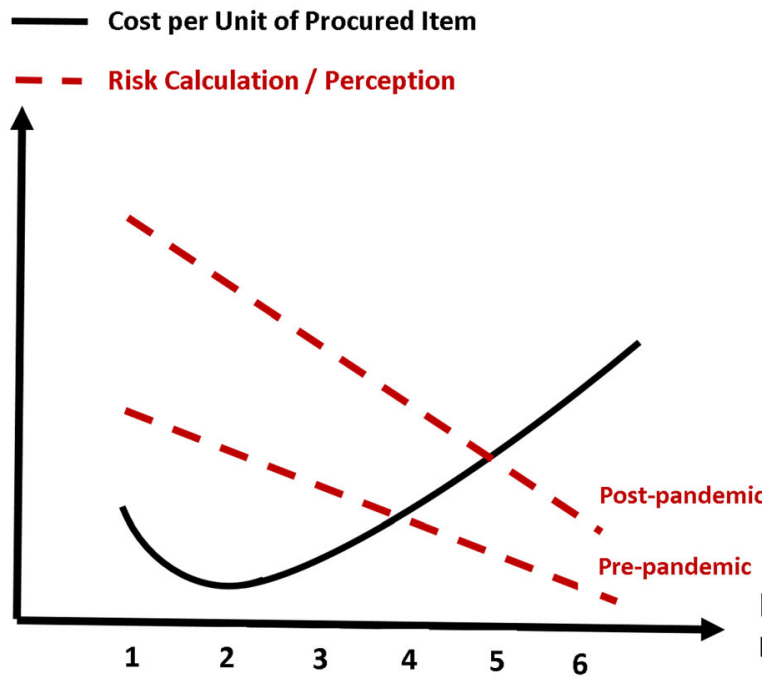

Increased GVC "Resilience" In Terms of:

(i) Number of Suppliers

(ii) Geographical diversification (iii) Propinquity of Sources (iv) Inventory levels

Figure 1 Trade-offs between GVC resilience and cost per unit. 
points reduces, and as inventory/sales ratios carried for the item in question increase. ${ }^{12}$ The optimum position is neither close to the extreme left of the $x$ axis nor far to the right, but somewhere in the middle.

Optimizing the supply chain is a balance between it being too lean on the above four indicators (in the interest of efficiency and low cost) and being too resilient or risk-averse. For instance, being too risk-averse and increasing inventory by more than a slight extent can put a firm at a competitive disadvantage. There is an echo of one of the variables in the J-curve hypothesis, found in Chen, Frank and $\mathrm{Wu}$ (2005) who showed that the stock market performance was best for US firms that held an intermediate level of inventory, as compared to rival firms that held too low, or too high, an inventory-to-sales ratio. This suggests that firms that are overly cautious in the future and carry too much inventory compared to rivals, or increase the number of worldwide suppliers by more than a marginal extent, will suffer a worse performance. (The exact shape of the J-curve will vary from one subsector to another.)

"Risk" can be a strategic perception, but can also be estimated by the MNE's Supply Chain Department using probabilistic models that include the likelihood of "stock-outs" and their consequences for each GVC configuration, in terms of lost sales or profits, as well as reputation. ${ }^{13}$ This will of course vary firm by firm. Figure 1 is a schematic representation.

Prior to February 2020, when perceived risks were lower, a MNE could be content to have two or three suppliers worldwide. With higher nationalism and protectionism, the post-pandemic risk curve lifts upwards (the higher dashed line in Figure 1), which calls for, or allows, increased resilience (e.g., more suppliers worldwide) - but only to a limited extent because costs per unit also rise to the right of the $x$ axis. Sensitivity to risk has increased. However, that will be offset by risk-reducing organizational and technical developments in GVCs, described below.

Hence the argument that the reconfiguration of GVCs will be small or marginal rather than radical. ${ }^{14}$ There are two reasons. First, much of globalization is driven by competition between companies based on price and cost. Efficiency and competitiveness require cost-cutting. Only a marginal increase in GVC costs can be tolerated. Second, supply chain risks can (and will) be mitigated by three digital technologies still in their infancy, (1) Blockchain, (2) Integration of VendorBuyer Computer Systems and (3) Artificial
Intelligence (AI) which produces predictive analytics (Lund et al., 2020; Kano \& Oh, 2020). In general, over the past 30 years, information technology and closer communication between buyers and suppliers has led to the growth of GVCs (Gunasekaran et al., 2017). However, even in 2020, to a surprising extent, the computer systems of MNEs are only loosely integrated with those of their foreign suppliers, so that a MNE procurement manager often does not exactly know the status of an order in the foreign factory or service provider.

Blockchain-based contracts lead to greater assurance, lower information asymmetry, and real-time information which reduces uncertainties, risks, and transaction costs (Schmidt \& Wagner, 2019; Kamilaris, Fonts \& Prenafeta-Boldu, 2019). Integration of computer systems, or the ability of the MNE to monitor, at any time, the status of the vendor's production by accessing their servers, reduces uncertainty and helps schedule the MNE's own sales, inventories, and other processes (Frazzon et al., 2018). Systems integrated via 5G will further reduce GVC risks by providing real-time information in transportation pathways (Rundle, 2020). Finally, the use of AI that incorporates data from weather, volcanoes, politics, economic cycles, competitor moves, commodity and other price levels, etc., should lead to more accurate forecasting of demand and hence lower risk in the management of GVCs (Lund et al., 2020).

In summary, while sensitivity to risk will increase in the post-pandemic era, at the same time there will be countervailing risk-reducing effects from new technologies which will reduce risks by improving the management and coordination of foreign supplier systems. (A fuller discussion of new technologies that reduce risks is taken up in a later section of this paper.) Most pertinently, as noted above, in competition with other global firms, price and cost cutting are of paramount importance. Hence, I argue that the numerical and geographical diversification of suppliers will occur only to a limited or marginal extent.

The imperatives of globalization will continue.

\section{THE OTHER IMPERATIVES OF GLOBALIZATION: MNES AS INTERNATIONAL BRIDGING AGENTS, TRANSFERORS, AND ARBITRAGEURS}

Why do multinational firms exist? In an atomistic, autarkic world, companies would remain domestic or national, and would deal across borders with 
other firms through contracts. International trade (sales of approximately $\$ 23$ trillion in goods and services in 2019), as well as an unnoticed but huge set of substitute transactions in the form of international licensing of intellectual assets (also resulting in foreign sales by licensees of $\$ 5$ trillion upwards ${ }^{15}$ in 2019), is legally covered by contracts although some significant portion is between related parties. ${ }^{16}$ Sales by MNE affiliates (not counting sales in the MNE's home nation) trump both at approximately $\$ 30$ trillion. Whatever the foreign market entry strategy, the multinational firm plays a dominant bridging role.

The MNE as the carrier or transmitter of internalized proprietary capabilities to affiliates in foreign locations, or Internalization Theory (Buckley \& Casson, 1976), has long lain at the heart of international business scholarship, and this core argument will not disappear in the future, even in a multi-polar, protectionist, or politics-driven world. The proprietary, internalized advantages or capabilities of successful international firms are alternatively described by Verbeke et al. (2018) as "firmspecific assets" which similarly result in the transfer of technologies (Monteiro, Arvidsson \& Birkinshaw, 2008), including the occasional reverse flow of ideas and knowledge from affiliates back to headquarters (e.g., Kumar, 2013).

MNEs also result in the spread of best practices in management (e.g., Kostova \& Roth, 2002), human resource management (HRM) (e.g., Ahlvik, Smale \& Sumelius, 2016), gender equality (e.g., Abe, Javorcik \& Kodama, 2016), sustainability (e.g., Marcon, de Medeiros \& Ribeiro, 2017), and ethics (e.g., Johnson, 2017). ${ }^{17}$ These contributions of MNEs will not disappear but will remain valid, even in a future world that may possibly be more nationalistic or fragmented (Petricevic \& Teece, 2019).

MNEs are diffusers of knowledge, both unconsciously (like birds or insects that propagate flora), as well as consciously. Even while attempting to keep their core proprietary technologies internalized, there is inevitably a leakage or "spillover" of some knowledge and best practices to local firms through employee mobility or simple imitation. This may be a negative for the international firm, reducing its competitive advantage vis-à-vis local competitors, but for the latter there is a beneficial learning process. For example, Swenson \& Chen (2014) found that the presence of international companies in locations in China resulted in improvement in the productivity, quality, frequency, and revenue capture of exports by local Chinese competitors in those regions.

Similarly, local firms learn as licensees of foreign companies. The World Bank (2020) reported that cross-border royalty payments for intellectual property crossed $\$ 400$ billion in 2018. These transactions are covered under a contractual alliance agreement where the licensor, or intellectual asset provider, has a self-interested incentive to teach their foreign partner the auxiliary production techniques beyond just the patent, design, brand, or licensed intellectual asset - for the simple reason that royalties are typically linked to licensee sales, and therefore the licensor has an incentive to help the licensee succeed. Even imports of physical products and services have a learning value to the importer (Grosse \& Fonseca, 2012).

International investment, trade, and licensing occur because of an arbitragable gap, or "distance", between nations in terms of knowledge, capital, know-how, and corporate capabilities - a gap that is unlikely to disappear after 2021.

\section{WHY, POST-PANDEMIC, THE WORLD ECONOMY WILL SEE EVEN MORE GLOBALIZATION}

The indispensable role played by the multinational enterprise (MNE) as a bridging agent that aggregates demand and arbitrages differences across nations, as well as orchestrates and conduits the cross-border flows of capital (FDI), goods and services (trade), and intellectual assets (in affiliates and in contractual sharing of knowledge and capabilities with licensing and alliance partners ${ }^{18}$ ), will not diminish, but remain even more needed in a post-pandemic world. In a world remaining fragmented and unequal, the MNE also plays a salutary role as a catalyst of higher institutional, governance, sustainability, HRM, environmental and ethics standards, both through its own affiliate network (Foss \& Pedersen, 2019) and by its external influence in countries that still have to catch up with "best practices."

The pandemic is more an accelerator of changes that were already under way rather than an event that enforces radically new patterns globally. Moreover, the impact of Covid-19 will affect a few nations and sectors more strongly than others. We have indeed seen, in the past three years and only in some nations, marginally more protectionism, nationalism, ${ }^{19}$ and calls for greater self-sufficiency. Mimicking trends espoused by the Trump 
Administration, India's Modi declared his hope to “... transform India into a more self-reliant country, making the goods and providing the services consumed in the country largely at home" (Roy, 2020). However, these trends are not entirely orthogonal to globalization. Waldman and Javidan (2020) describe this as a "false dichotomy."

Protectionism and nationalism can even increase the geographical "footprint" of the MNE if trade barriers lead to increased tariff-jumping FDI (Buckley, 2020). For example, China's long tradition of protecting its automobile sector has resulted in substantial FDI investments by western companies from Volkswagen to General Motors to Tesla. Not only do the foreign companies dominate but, for some of them, China is their largest and most profitable market; moreover, Chinese industry has benefited greatly from the transfer of technology, designs, productivity, and best practices to China (Buckley, Clegg, Zheng, Siler, \& Giorgioni, 2010).

Nationalist policies can sometimes increase globalization, a seemingly paradoxical effect. Glennon's (2020) study concludes that the more stringent enforcement of H1-B visas by the Trump Administration has already seen an increase in the offshoring of technological jobs. As a global orchestrator or network organizer, the international firm has more than one conduit of opportunity to enable cross-border transfers. If migration of talent is constrained, it can be replaced by remote virtual work. Observers suggest that, post-pandemic, more service functions will be carried out remotely (Tilley, 2020). However, by the same logic (i.e., the "Zoom Effect"), that job can be done even more remotely from Sofia or New Delhi. True, geographical and cultural distances impose higher organizational and transaction costs on the firm (Larson, Vroman, \& Makarius, 2020), but these can be more than offset by the labor cost saving. Since there is no proposal to restrict the hiring of remote foreign employees, the "Zoom effect" and the growing worldwide familiarity with the "gig economy" can lead to even more offshored work. For example, while cross-border telemedicine faces significant regulatory barriers in advanced nations (Ferreira \& Rosales, 2020), this is not the case everywhere. Instead of the patient crossing borders to visit the hospital abroad, some diagnoses and treatments will increasingly occur remotely.

Petricevic and Teece (2019) correctly identify the rekindling of the idea of government intervention in the foreign direct investment process. While most of the rest of the world has been lifting restrictions - liberalizing incoming FDI and eliminating lists of sectors requiring prior governmental approval (UNCTAD, 2019) and under the general rubric of "Ease of Doing Business" (World Bank, 2019) - the two biggest investors, China and the US, have been tightening scrutiny and vetoing a few proposed investments. The CFIUS (Committee on Foreign Investment in the United States) scrutinizes large FDI proposals for national security ${ }^{20}$ concerns and is comprised of nine cabinet members, with the Treasury Secretary as Chair, and aided by senior intelligence officials. Ostensibly, China proclaims itself as a "champion of globalization" (Wang \& Quan, 2019). China's new "Foreign Investment Law" promulgated in January 2020 has slightly relaxed inward FDI regulations, reduced its "negative list", and promises "national treatment" (Dresden \& Xia, 2020). However, the interventionist hand of the state remains just below the surface.

The few vetoes of FDI proposals in the US, and even rarer such occurrences in Europe, constitute an insignificant fraction-of-one-percent of overall global flows. Anxieties elevated by the pandemic having abated, most countries may become more vigilant, but will resume their welcome towards FDI simply because it adds net value to the host nation. Petricevic and Teece (2019) go too far in characterizing the future of globalization as a "structural reshaping." They are correct in highlighting the rising techno-political rivalry between the US and China. Almost their entire paper (except for the first two pages) refers to - and is colored by - this bilateral relationship. ${ }^{21}$ While China and the US remain the two biggest economies and direct investors, and they may partially decouple from each other, it is too much of a stretch to extrapolate this possible rivalry to the rest of the 191 nations on the planet. Only a handful of other nations will add some sectors to their list of "strategic industries." The fact remains that the vast bulk of FDI is in "...non-strategic sectors, such as agriculture, fashion, consumer goods, and even insurance." (Petricevic \& Teece, 2019, p. 1502). Even in the US, an examination of Chinese FDI investments between January 2007 and June 2020 shows only a small percentage in technology-related sectors (American Enterprise Institute, 2020). ${ }^{22}$ For all countries' MNEs seeking to invest in the US, CFIUS conducted 561 reviews for the entire 9-year period, 2009-2017, of which 145 FDI proposals were withdrawn during the investigation, and only 3 or 5 were vetoed by presidential order (Jackson, 2020). ${ }^{23}$ 
Buckley (2020) takes a balanced view, stating that "the fracture (between the US and China) may not be complete, nor be the only global policy change of significance in the post-virus world" (parentheses added). As noted in this piece above, I propose that, after the post-pandemic hiatus, globalization will resume and that changes will be marginal or incremental rather than structural.

\section{REDUCING RISKS IN A POST-PANDEMIC WORLD}

We are likely to see a world where perception of risks will be marginally increased. However, these risks will be ameliorated or counteracted by changes that were already underway, which augur an even more coordinated global economy:

1. More sophisticated information systems amongst MNEs and Traders: Volatility, Uncertainty, Complexity and Ambiguity (VUCA) are reduced “...by the increased collection of information ...with greater transmission and coordination of informational resources..." (Buckley, 2020). Liesch and Welch (2019) make a similar argument. In practical terms, this means linking and integrating the computer systems of GVC buyers and vendors in real-time, so that the exact status of an order under production, as well as a vendor's schedules, are instantly available and transparent to the MNE or importer. Second, in transit across borders, 5G and satellite technology will further pinpoint the tracking of shipments (Rundle, 2020). Third, Bughin et al. (2017) show the huge - as yet unutilized - potential for the increased use of AI in global scanning and strategic planning, including demand forecasting in various national markets, forecasting and managing political or weather-related risks, input costs and selling prices, and optimization of transport and logistics, as well as culturallyadaptive marketing. These coming information technology advances are poised to reduce risk.

2. Closer relationships between suppliers and buyers: Verbeke (2020) and Kano (2018) suggest that even stronger joint "relational governance", accompanied by a willingness to be flexible when disruptions threaten GVCs, can further handle risk by substituting for, or augmenting, the digitized information flows discussed above. This echoes somewhat with the rather venerable concept of "keiretsu" in Japanese supply chains, where interfirm cooperation, homophily, and a familial relationship were aided by symbolically small cross-shareholdings between the focal firm and its constellation of suppliers (e.g., Lincoln, Gerlach, \& Takahashi, 1992).

3. Marginal increase in the diversification of input and assembly-point sources: As a reaction to perceived risks, diversification is likely to be manifested in a slight increase in the numbers of vendors, alliance partners and source nations, per MNE. Buckley (2020) alludes to the greater flexibility this diversification provides by increasing the size of the "portfolio" of partners, especially if each partner has versatile and flexibly deployable assets, and the entire partner network is willing to share information for mutual efficiency. As proposed above in the J-curve paradigm (see Figure 1), the marginal increase in sources can increase costs per unit procured ceteris paribus. However, even that unit cost increase is conditional upon minimum economies of production scale compared with the various sizes of the national markets the MNE serves. Moreover, if the incremental vendor added is closer to the customer, the increase in the average unit production labor cost can be offset by the shorter logistical distance - for example, the partial substitution of a Mexican assembly operation (average distance $1629 \mathrm{~km}$ ) instead of Chinese production (average distance $11,671 \mathrm{~km})$.

Risk can also decrease with the use of alliance partners in R\&D. The increased complexity of development and finished product design means that even large MNEs do not possess internally sufficient knowledge or efficiency for all aspects of research. The R\&D portion of the value chain is increasingly "dis-internalized" and slices of the development process shared with partners. This results in speedier and lower-cost results; moreover, developmental risks are shared and reduced for the focal MNE (Contractor et al., 2010). Occasionally, valuable novel or idiosyncratic ideas can be accessed by including innovation partners in emerging nations (Ramamurti, 2016).

4. A weighted-average decrease in "distance": This can be measured multidimensionally as per Berry, Guillén and Zhou (2010) in terms of cultural, political, and geographical distances between the MNE and its network partners). In addition, 
the GVC network will see (only a partial) locational shift or decoupling between US MNEs and Chinese sources. For example, Ha \& Phuc (2019) show the benefit derived by Vietnam from the relocation of sourcing from China as a result of the Trump tariffs. However, that geographical shift had begun years earlier in reaction to rising Chinese labor rates. $^{24}$

5. Common standards - The hidden plumbing of globalization: Imagine a world where each town maintained its own local time, where dimensions, voltages, current, nomenclature, and symbols varied not just from one country to another but from one firm to another. International trade, coordination, and competition were severely limited. Such a world prevailed until the International Meridian Conference of 1884 divided the world into 24 time zones, and in the year 1901 when the Engineering Standards (International) Committee met in London to begin to formulate common technical standards.

Internationally adopted standards lower risk by reducing information asymmetries, providing transparency, comparability, interoperatibility, scale advantages, and accountability, and supplying a common technical language that facilitates global commerce. Technology standards "...directly affect at least $80 \%$ of international trade," according to Purcell, Kushnier and Law (2016).

I do not aver that common standards cause or trigger globalization. Rather, common technical standards are a necessary precondition and concomitant of globalization - its hidden plumbing. A technological civilization cannot exist without the world, or at least large enough coalitions of firms, adopting common standards. In a quiet, unheralded way under the aegis of organizations such as the ISO (International Organization for Standardization) and the World Bank, crossborder industry conferences and multinational committees have quietly hammered out jointly acceptable protocols on almost the entire range of products and services, from clinical trials ${ }^{25}$ (Idänpään-Heikkilä, 1994), to air traffic (International Civil Aviation Guidelines), to financial transactions and remittances, to satellite and GPS receivers, to mobile telephony, to phytosanitary standards in food, horticulture, and medicine (Ramakrishnan, 2016), to insurance, to cybersecurity (Wilkins, 2020), to piping and instrumentation, to smart buildings, to corporate social responsibility (CSR), and to ethics (Nadvi, 2008), etc. A complete list of products and services under international standards would require thousands of pages.

A huge boost to the global expansion of trade occurred in 1965 when, after a three-year negotiation, ISO delegates from a dozen nations finalized the design of standardized shipping containers, resulting in an at least three-quarters reduction in freight and insurance costs, compared with the old system of "breakbulk freight", or the loading of individual cargo of miscellaneous shapes and sizes into the belly of a ship (Levinson, 2020).

The standardization process is not only incomplete, but, with new developments and accelerating technical growth, international standardization will be even more needed in the future.

\section{CONCLUSIONS}

After the pandemic, the "new normal" may be marginally different, but globalization in its various manifestations will continue, and global coordination will be even more important for collective intergovernmental action to meet future pandemics, climate change, emerging technologies, and international tax-avoidance, to set common product and technical standards, and to address the growing sensitivity of customers worldwide to sustainability, ethics, and CSR issues.

A greater degree of nationalism and protectionism need not impede FDI and in some cases may even increase it by inducing more tariff-jumping investments. Alliances such as international joint ventures and contractual alliances such as licensing of intellectual property, circumvent protectionism, and substitute for exports or FDI as a means of reaching foreign customers. In fact, over 1990-2019, licensing royalties (and the foreign sales resulting from the transfer of intellectual assets) have been the fastest-growing method of international business (10.13\% compound annual growth rate or CAGR) versus world exports $(6.62 \%$ CAGR) versus FDI flows (6.37\% CAGR). ${ }^{26}$ In comparing the global strategic importance of FDI, trade, and licensing (loose contractual alliances), scholars have to be careful with the raw numbers. All three foreign market entry alternatives are biased by international tax avoidance, double-counting, and 
under-reporting biases. Nevertheless, it is clear that all three international business indicators have grown at a faster rate than the average growth rate of GDP (4.9\% CAGR). This illustrates the value and continued rationale for cross-border commerce, and the unique role played by the MNE as a agent that aggregates demand and arbitrages differences across nations, as well as orchestrates and conduits the cross-border flows of capital (FDI), goods and services (trade), and intellectual assets (in affiliates and in contractual sharing of knowledge and capabilities with licensing and alliance partners),

The art of global management has always been to seek the optimum middle ground between integration and fragmentation, between standardization and adaptation, and between resilience or assurance on the one hand and efficiency/cost reduction on the other. The global manager knows how to manage risk. In MNEs and governments, there will be a greater awareness of political and GVC risks. However, at the same time, this article has highlighted several risk-reducing methods and emerging technologies whereby global risks can be ameliorated. A small or marginal increase in surge or spare capacity (for "strategic" items), a small increase in inventories at point-of-demand, and the number of suppliers can slightly increase procurement costs per unit.

On the other hand, these incremental costs can be reduced or avoided altogether by implementing better information-gathering systems, 5G surveillance and monitoring, blockchain and other integration of vendor-buyer computer systems, AIbased demand and inventory prediction, relationship-based alliances (Kano \& Oh, 2020), and the continuing evolution and consensus on common technical and governance standards.

One should not overstate the current rift between the US and China as a portent of the business environment to come. In certain technologies, such as $5 \mathrm{G}$, there may indeed be an unfortunate bifurcation of technical standards. However, overall, the "Brussels Effect" 27 is likely to play a more powerful, albeit quiet role in shaping global commerce (Bradford, 2020). EU rules and standards, adopted around the world, on issues ranging from green technology, data protection (GDPR), antitrust and competition rules, ethics, international law, arbitration, and technical standards ranging from AI to zucchini ${ }^{28}$ (and to a lesser extent California standards) exert a disproportionate extraterritorial influence leading to "harmonization" and a lower-risk strategic planning environment.

We are building a global technological civilization, undergirded by common understandings, consensus, and cooperation. History has had examples of U-turns. The glories of Rome, Chang An, and Pataliputra were followed by some darker periods. However, today, the cross-border flow of information, spread of education, literacy, knowledge, and technology have progressed to a global scope and developed a nascent global consciousness, which makes it more difficult (although not impossible) for regression. The post-pandemic world is likely to need, and witness, even more globalization.

\section{NOTES}

${ }^{1}$ Individual examples can easily be found where the direct and indirect costs of an international investment project, or a particular kind of trade, are higher than the benefits it produces. However, that does not obviate the unequivocal overall net benefits produced by globalization. Admittedly also, the net benefits produced by globalization are not shared equally across nations, some of which may have had their industrialization stage in economic development prematurely aborted by the shift of manufacturing to more dynamic producers like China (Rodrik, 2016; Larson et al., 2016), as well as the general shift to a services-based global economy (Levinson, 2020). However, these are not issues pursued in this Point article.

${ }^{2}$ From World Bank data: https://data.worldbank. org/indicator/BX.KLT.DINV.CD.WD. And, of course, the numbers for 2020 , and a year or two following, are likely to represent a significant drop.

${ }^{3}$ The number of MNEs from the Fortune Global 500 list, deemed by the authors to be "global," increased from a count of 9 in 2004 to 36 firms in 2017, using their perhaps overly-stringent criterion that a global firm must have "at least $20 \%$ of their sales in all three regions of the triad, but less than $50 \%$ in any one region." This does not measure sales of a company's products worldwide through trade, contractual alliances, and minority equity joint ventures, all of which are not separately counted in UNCTAD or World Bank data. Nevertheless, Rugman \& Verbeke's (2004) overall conclusion is correct, that most MNEs principally serve their home and contiguous regions. 
${ }^{4}$ https://data.worldbank.org/indicator/BX.GSR. ROYL.CD.

${ }^{5}$ Most royalties are linked by a formula as a percentage of sales achieved by the licensee/alliance partner. Compared to the profit of a FDI affiliate, licensee sales are axiomatically far less volatile, for two reasons/ First, sales of any firm are far less volatile than profits. Secondly, royalties are steady because the agreement remains in force for the number of years of the alliance agreement. Returns from licensing out intellectual assets are hence intrinsically more steady and assured compared with foreign affiliate dividends. FDI flows are also more volatile and sensitive to business cycles, because a FDI involves a conscious initial investment decision, made in return for the expected discounted cash flow of future affiliate profits. Hence FDI falls off in recessionary periods.

${ }^{6}$ The latter figure is an overestimate. However, unfortunately we have no comprehensive information on international royalty rates, this being a gaping data hole in international business and economics studies. We only have some sketchy figures from consultants (e.g, Podlogar, 2018). Using the typical "reasonable" average royalty rate of $5 \%$, touted by licensing negotiators, by dividing the royalty remittances by a factor of 0.05 , we get an estimate for foreign licensee sales stemming from licensed intellectual property at $\$ 7945$ billion. This is smaller than "World Exports (i.e. Sales)" or "Sales by MNEs Outside Their Home Country". Nevertheless, licensing of intellectual assets constitutes an inescapably important, albeit neglected, component of global strategy.

${ }^{7}$ Undoubtedly, a tiny minority of FDI cases produce negative effects on the host country. However, that does not obviate the overall conclusion of the beneficial impact of FDI.

${ }^{8}$ Of course, there are some net costs of international business and globalization. However, these are, on average, more than offset by the benefits.

${ }^{9}$ This argument sounds similar to the advantage of larger firm size, except that the MNE, by expanding abroad, transcends or escapes the operational size limitation that constrains domestic competitors. Also, this paragraph addresses the benefits of size or global scale but with a specific focus on the amortization of $R \& D$ and central overheads in the MNE as opposed to scale economies in production, where factory-level fixed costs, spread over more units of output, reduce average cost per production unit.
${ }^{10}$ Easy scalability, accompanied by network effects, can also occasionally lead to oligopolies and monopolies, as we see in digital services such as Google or Facebook (e.g., Smyrnaios, 2018). However, this is not a widespread phenomenon and is not the focus of this article.

${ }^{11}$ The author, despite many searches, has been unable to find a Supply Chain Management paper where the cost per unit of procurement has been theorized or mapped as a function of the number of supply sources. This is likely a research opportunity.

${ }^{12}$ For US-based firms, the inventory-to-sales ratio had been declining since 1981 but then increased from a low of 1.25 in 2010 to 1.39 in June 2020 according to the US Census Bureau. https://www. census.gov/mtis/www/data/pdf/mtis_current.pdf.

${ }^{13}$ Again, the author has been unable to find papers that go in this direction, in which case this is a research opportunity for Supply Chain Management or IB scholars.

${ }^{14}$ With rising geo-political tensions, perhaps the most noticeable changes in global GVCs will be for supply sources from China, where the plateauing labor force has also seen labor costs escalate at well above China's inflation rate between 2010 and 2020.

${ }^{15}$ Estimates can range up to an unlikely $\$ 19$ trillion, depending on our assumption of the global average royalty rate, which is unknown.

${ }^{16}$ The data have to be interpreted with great circumspection, however, because of double-counting and interrelatedness. UNCTAD (2013) estimated that a multinational firm functioning as either exporter or importer was involved in threequarters of world trade. Some reports suggest that intrafirm trade is $40 \%$ of the world total. In the licensing or contractual alliance category, an unknown fraction of deals, for tax-avoidance reasons, are between a MNE and its own foreign affiliate as licensee. All said, the MNE plays a dominant role in all three modes of foreign entry.

${ }^{17}$ The upgrading of standards may be weaker, but only in some cases, when FDI is between emerging nations. For example, the literature on Chinese FDI in Africa admits that there is an overall economic benefit, but takes a more circumspect view of managerial and HRM practices used by Chinese managers within their affiliates and projects in Africa (e.g., Jackson, 2014). 
${ }^{18}$ Many IB scholars still seem to be not fully aware that IJVs are today covered by as detailed and long an agreement as in contractual or "non-equity" alliances, both of which are based on the letter of the agreement, as well as the relationship, although the relationship is, on average, stronger and deeper in IJVs than in contractual alliances (Velez-Calle, 2018; Contractor \& Reuer, 2019). Both lie along a spectrum that can be described as "quasiinternalization."

${ }^{19}$ The various aspects and nuances of nationalism are a complex subject which deserves a more richly textured analysis than can possibly be covered in this article.

${ }^{20}$ What comprises "national security" is of course open to question and to political considerations.

${ }^{21}$ The word "China" is not seen in the first 771 words of the introduction to Petricevic and Teece's (2019) paper. However, "China" then occurs as many as 224 times throughout the rest of their article.

${ }^{22}$ In the largest 20 Chinese investments between 2009 and 2017 which exceeded \$2 billion, aircraft leasing and food (pork) companies were the two biggest American targets, others including innocuous sectors such as entertainment, textiles, tourism, real estate, and consumer white goods. In the top20 list, there were four technology companies, but these included peripherals such as printers (Lexmark) and personal computers (IBM personal computer division purchased by Lenovo).

\section{REFERENCES}

Abdelal, R. 2020. Of learning and forgetting: Centrism, populism, and the legitimacy crisis of globalization. In Harvard business school, working paper 21-008, July.

Abe, Y., Javorcik, B., \& Kodama, N. 2016. Multinationals and female employment: Japanese evidence. Centre for Economic Policy Research. https://voxeu.org/article/multinationals-andfemale-employment-japanese-evidence.

Ahlvik, C., Smale, A., \& Sumelius, J. 2016. Aligning corporate transfer intentions and subsidiary HRM practice implementation in multinational corporations. Journal of World Business, 51(3): 343-355.

Altman, S., \& Bastian, P. 2019. DHL Global Connectedness Index 2019 Update, Bonn, DHL and NYU Stern School of Business

American Enterprise Institute. 2020. China global investment tracker. https://www.aei.org/wp-content/uploads/2020/07/ US-China-Tracker_July-2020.xlsx.

Aylor, B., DeFauw, M., Gilbert, M., Knizek, C., Lang, N., KochWeser, J. \& McAdoo, M. 2020. Redrawing the map of global trade. Boston Consulting Group, July 20, Boston. https:// www.bcg.com/publications/2020/redrawing-the-map-ofglobal-trade?utm_medium=Email\&utm_source=esp\&utm campaign=none\&utm description=ealert\&utm topic $=$ none\&utm_geo $=$ global\&utm_content $=202008 \&$ utm usertoken=ea5d31c9eface5908574b9100817aff75d5a50a0.
${ }^{23}$ Of course, the numbers do not include prospective Chinese investments that may not have been initiated in the first place, because of fear of refusal.

${ }^{24}$ For the foreseeable post-pandemic future, the shift away from Chinese sources is likely to be small, partial and manageable because (1) other nations like Vietnam do not have as large a labor pool, (2) to some extent, rising Chinese labor costs have already been offset by the greater use of automation in Chinese factories, (3) it is not easy to replicate the sub-contractor and knowledge clusters in Chinese cities that have specialized in certain product types, and (4) the anti-China animus in the US and some other nations may not escalate further.

${ }^{25}$ Good clinical practice guidelines developed by the International Conference on Harmonization and first published in May 1996.

${ }^{26}$ World Bank Data: data.worldbank.org.

${ }^{27}$ While the US federal government has, at least temporarily, abdicated its role as an exemplar and standard-setter, the European Union (EU) has quietly had a big impact in establishing standards of corporate conduct and trade, as well as technology.

${ }^{28}$ The EU name for zucchini is "courgettes".

${ }^{29}$ https://data.worldbank.org/indicator/

BX.GSR.ROYL.CD.

Baldwin, R., \& Tomiura, E. 2020. Thinking ahead about the trade impact of COVID-19. Economics in the Time of COVID-19 (pp. 59-72).

Berghuis, E., \& den Butter, F. A. 2017. The transaction costs perspective on international supply chain management; evidence from case studies in the manufacturing industry in the Netherlands. International Review of Applied Economics, 31(6): 754-773.

Berry, H., Guillén, M. F., \& Zhou, N. 2010. An institutional approach to cross-national distance. Journal of International Business Studies, 41(9): 1460-1480.

Bradford, A. 2020. The Brussels effect: How the European Union rules the world. Oxford: Oxford University Press.

Buckley, P. J. 2020. The theory and empirics of the structural reshaping of globalization. Journal of International Business Studies, 51: 1580-1592.

Buckley, P. J., \& Casson, M. C. 1976. The future of the multinational enterprise. London: Macmillan.

Buckley, P.J., Clegg, J., Zheng, P., Siler, P.A., \& Giorgioni, G. 2010. The impact of foreign direct investment on the productivity of China's automotive industry. In Foreign direct investment, China and the world economy: 284-304. London: Palgrave Macmillan. 
Bughin, J., Hazan, E., Ramaswamy, S., Chu, M., Allas, T., Dahlström, P., Henke, N., \& Trench, M. 2017. Artificial intelligence the next digital frontier? In McKinsey Global Institute, discussion paper 47. June.

Cantwell, J. 2015. The eclectic paradigm: A framework for synthesizing and comparing theories of international business from different disciplines or perspectives. London: Palgrave Macmillan.

Caves, R. E. 1974. Multinational firms, competition, and productivity in host-country markets. Economica, 41(162): 176-193.

Chandler, A. D., \& Hikino, T. 2009. Scale and scope: The dynamics of industrial capitalism. Cambridge: Harvard University Press.

Chen, H., Frank, M. Z., \& Wu, O. Q. 2005. What actually happened to the inventories of American companies between 1981 and 2000? Management Science, 51(7): 1015-1031.

Contractor, F. J. 2019. Can a firm find the balance between openness and secrecy? Towards a theory of an optimum level of disclosure. Journal of International Business Studies, 50(2): 261-274.

Contractor, F. J., Dangol, R., Nuruzzaman, N., \& Raghunath, S. 2020. How do country regulations and business environment impact foreign direct investment (FDI) inflows? International Business Review, 29(2): 101640.

Contractor, F. J., Kumar, V., Kundu, S. K., \& Pedersen, T. 2010. Reconceptualizing the firm in a world of outsourcing and offshoring: The organizational and geographical relocation of high-value company functions. Journal of Management Studies, 47(8): 1417-1433.

Contractor, F. J., \& Reuer, J. J. 2019. Frontiers of alliance research. Cambridge: Cambridge University Press.

Dresden, M. \& Xia, S. 2020. How China's new foreign investment law affects you (or not) China Law Blog, (February 24), https://www.chinalawblog.com/2020/02/how-chinasnew-foreign-investment-law-affects-you-or-not.html.

Dunning, J. H. 2015. The eclectic paradigm of international production: A restatement and some possible extensions. In The eclectic paradigm: 50-84. London: Palgrave Macmillan.

Ferreira, W. \& Rosales, A. 2020. International telemedicine: A global regulatory challenge. In: Hogan Lovells, March 9. https://www.lexology.com/library/detail.aspx?g=f2d9946be5c3-43f5-b813-9528e23afbda.

Fontaine, R. 2020. Globalization will look very different after the coronavirus pandemic. In: Foreign policy, April 17. https:// foreignpolicy.com/2020/04/17/globalization-trade-war-aftercoronavirus-pandemic/.

Foss, N. J., \& Pedersen, T. 2019. Microfoundations in international management research: The case of knowledge sharing in multinational corporations. Journal of International Business Studies, 50(9): 1594-1621.

Frazzon, E., Albrecht, A., Pires, M., Israel, E., Kück, M., \& Freitag, M. 2018. Hybrid approach for the integrated scheduling of production and transport processes along supply chains. International Journal of Production Research, 56(5): 2019-2035.

Ghemawat, P. 2007. Managing differences: The central challenge of global strategy. Harvard Business Review, 85(3): $58-68$.

Glennon, B. 2020. How do restrictions on high-skilled immigration affect offshoring? Evidence from the H-1B Program (Wharton School Working Paper, February 21, 2020). Available at SSRN: https://ssrn.com/abstract=3547655 or http:// dx.doi.org/10.2139/ssrn.3547655.

Grosse, R., \& Fonseca, A. 2012. Learning through imports in the internationalization process. Journal of International Management, 18(4): 366-378.

Gunasekaran, A., Subramanian, N., \& Papadopoulos, T. 2017. Information technology for competitive advantage within logistics and supply chains: A review. Transportation Research Part E: Logistics and Transportation Review, 99: 14-33.
Ha, L.T., \& Phuc, N.D. 2019. The US-China trade war: Impact on Vietnam. In Asian Development Bank Yusof Ishak Institute working paper. http://hdl.handle.net/11540/11697.

Idänpään-Heikkilä, J. E. 1994. WHO guidelines for good clinical practice (GCP) for trials on pharmaceutical products: Responsibilities of the investigator. Annals of Medicine, 26(2): 89-94.

Ivanov, D., \& Dolgui, A. 2020. Viability of intertwined supply networks: extending the supply chain resilience angles towards survivability. A position paper motivated by COVID19 outbreak. International Journal of Production Research, 58(10): 2904-2915.

Jackson, T. 2014. Employment in Chinese MNEs: Appraising the dragon's gift to sub-Saharan Africa. Human Resource Management, 53(6): 897-919.

Jackson, J. 2020. The committee on foreign investment in the United States (CFIUS). In Congressional research service, Washington, D.C. https://fas.org/sgp/crs/natsec/RL33388.pdf.

Johnson, T. (Ed.). 2017. Globalization and the ethical responsibilities of multinational corporations: Emerging research and opportunities. Hershey, PA: IGI Global.

Jude, C. \& Levieuge, G. 2015. Growth effect of FDI in developing economies: The role of institutional quality. In Banque de France working paper no. 559. https://papers.ssrn. $\mathrm{com} / \mathrm{sol} 3 /$ papers.cfm?abstract_id=2620698.

Kamilaris, A., Fonts, A., \& Prenafeta-Bold'́, F. X. 2019. The rise of blockchain technology in agriculture and food supply chains. Trends in Food Science \& Technology, 91: 640-652.

Kano, L. 2018. Global value chain governance: A relational perspective. Journal of International Business Studies, 49(6): 684-705.

Kano, L., \& Oh, C. H. 2020. Global value chains in the postCOVID world: Governance for reliability. Journal of Management Studies, 57: 1773-1777. https://doi.org/10.1111/joms. 12626.

Katsikeas, C. S., Samiee, S., \& Theodosiou, M. 2006. Strategy fit and performance consequences of international marketing standardization. Strategic Management Journal, 27(9): 867-890.

Kostova, T., \& Roth, K. 2002. Adoption of organizational practice by subsidiaries of multinational corporations: Institutional and relational effects. Academy of Management Journal, 45(1): 215-233.

Kumar, N. 2013. Managing reverse knowledge flow in multinational corporations. Journal of Knowledge Management, 17(5): 695-708.

Larson, G.M., Loayza, N., \& Woolcock, M. 2016. The middleincome trap: myth or reality? In World bank research and policy briefs, March 2016.

Larson, B., Vroman, S., \& Makarius, E. 2020. A guide to managing your (newly) remote workers. Brighton: Harvard Business Review.

Levinson, M. 2020. Outside the box: How globalization changed from moving stuff to spreading ideas. Princeton: Princeton University Press.

Liesch, P. W., \& Welch, L. S. 2019. The Firms of Our Times: Risk and Uncertainty. In International business in a VUCA world: The changing role of states and firms (progress in international business research, vol. 14): 41-53. Emerald.

Lincoln, J. R., Gerlach, M. L., \& Takahashi, P. 1992. Keiretsu networks in the Japanese economy: A dyad analysis of intercorporate ties. American Sociological Review, 57: 561-585.

Lund, S., Manyika, J., Woetzel, J., Barriball, E., Krishnan, M., Alicke, K., Birshan, M., George, K., Smit, S., Swan, D., \& Hutzler, K. 2020. Risk, resilience, and rebalancing in global value chains. McKinsey Global Institute. https://www.mckinsey. com/business-functions/operations/our-insights/riskresilience-and-rebalancing-in-global-value-chains\#.

Marcon, A., de Medeiros, J. F., \& Ribeiro, J. L. D. 2017. Innovation and environmentally sustainable economy: Identifying the best practices developed by multinationals in Brazil. lournal of Cleaner Production, 160: 83-97. 
Miroudot, S. 2020. Resilience versus robustness in global value chains: Some policy implications. In COVID-19 and trade policy: Why turning inward won't work: 117-130. VoxEU/CEPR. https://voxeu.org/article/resilience-versus-robustness-globalvalue-chains.

Monteiro, L. F., Arvidsson, N., \& Birkinshaw, J. 2008. Knowledge flows within multinational corporations: Explaining subsidiary isolation and its performance implications. Organization Science, 19(1): 90-107.

Moran, T., Graham, E., \& Blomström, M. 2005. Does foreign direct investment promote development?. New York: Columbia University Press.

Nadvi, K. 2008. Global standards, global governance and the organization of global value chains. Journal of Economic Geography, 8(3): 323-343.

Petricevic, O., \& Teece, D. J. 2019. The structural reshaping of globalization: Implications for strategic sectors, profiting from innovation, and the multinational enterprise. Journal of International Business Studies, 50(9): 1487-1512.

Podlogar, E. 2018. Intellectual property trends: Average royalty rates, most active industries, and more. In BVR/ktMINE royalty rate benchmarking guide (Chapter 18). https://www. bvresources.com/blogs/intellectual-property-news/2018/04/ 18 /intellectual-property-trends-average-royalty-rates-mostactive-industries-and-more.

Prud'homme, D. 2019. Re-conceptualizing intellectual property regimes in international business research: Foreign-friendliness paradoxes facing MNCs in China. Journal of World Business, 54(4): 399-419.

Purcell, D., Kushnier, G. \& Law, D. 2016. Globalization and standardization. IEEE Standards University. August. https:// wWW.standardsuniversity.org/e-magazine/august-2016volume-6/globalization-and-standardization/.

Ramakrishnan, K. 2016. From local to global ambitions: The benefits of standards compliance. In World bank blog, July 5. https://blogs.worldbank.org/trade/local-global-ambitionsbenefits-standards-compliance.

Ramamurti, R. 2016. Internationalization and innovation in emerging markets. Strategic Management Journal, 37(13): 74-83.

Rodrik, D. 2016. Premature deindustrialization. Journal of Economic Growth, 21(1): 1-33.

Rosa, B., Gugler, P., \& Verbeke, A. 2004. Regional and global strategies of MNEs: Revisiting Rugman and Verbeke. Journal of International Business Studies, 51: 1045-1053.

Roy, R. 2020. India's leader calls for economic self-sufficiency, promises relief. Wall Street Journal, May 12.

Rugman, A. M., \& Verbeke, A. 2004. A perspective on regional and global strategies of multinational enterprises. Journal of International Business Studies, 35(1): 3-18.

Rundle, J. 2020. 5G promises radical overhaul for supply chains. Wall Street Journal, April 12, https://www.wsj.com/articles/5gpromises-radical-overhaul-for-supply-chains-11586556432.

Schmidt, C. G., \& Wagner, S. M. 2019. Blockchain and supply chain relations: A transaction cost theory perspective. Journal of Purchasing and Supply Management, 25(4): 100552.

Sherman, E. 2020. 94\% of the Fortune 1000 are seeing coronavirus supply chain disruptions, Fortune, February 21.

Smyrnaios, N. 2018. Internet oligopoly: The corporate takeover of our digital world. Bingley: Emerald.

Swenson, D. L., \& Chen, H. 2014. Multinational exposure and the quality of new Chinese exports. Oxford Bulletin of Economics and Statistics, 76(1): 41-66.

Tilley, A. 2020. Zoom targets prolonged remote-work era as coronavirus drags on. Wall Street Journal, July 15.

UNCTAD. 2013. World investment report 2013: Global value chains: Investment and trade for development. New York: United Nations.

UNCTAD 2019. Investment policy monitor no. 22. (December). https://unctad.org/en/PublicationsLibrary/ diaepcbinf2019d8_en.pdf.
UNCTAD. 2020. World investment report 2020: International production beyond the pandemic. New York: United Nations.

Velez-Calle, A. 2018. Joint venture governance: A dissection of agreements and their anatomy. Doctoral dissertation, Rutgers University-Graduate School-Newark.

Verbeke, A. 2020. Will the COVID-19 pandemic really change the governance of global value chains? British Journal of Management, 31(3): 444-446.

Verbeke, A., Coeurderoy, R., \& Matt, T. 2018. The future of international business research on corporate globalization that never was...". Journal of International Business Studies, 49: $1101-1112$

Waldman, D., \& Javidan, M. 2020. The false dichotomy between globalism and nationalism. Brighton: Harvard Business Review.

Wang, Z. \& Quan, S. 2019. How China is drawing on its own history to champion globalisation, peace and prosperity. South China Morning Post. October 3. https://www.scmp.com/ comment/opinion/article/3031131/how-china-drawing-itsown-history-champion-globalisation-peace-and.

Wilkins, M. 2020. What is the value of industry standards in Today's world? ARC advisory group, https://www.arcweb. com/blog/what-value-industry-standards-todays-world.

Witt, M. A. 2019. De-globalization: Theories, predictions, and opportunities for international business research. Journal of International Business Studies, 50(7): 1053-1077.

World Bank. 2019. Doing business 2020. Washington, DC: World Bank.

World Bank. 2020. Charges for the use of intellectual property, receipts (BoP, current US\$). https://data.worldbank.org/ indicator/BX.GSR.ROYL.CD.

Young, J. 2020. China, Covid-19 and the end of globalisation as we knew it. MSN Newsroom, April 10. https://www.msn.com/ en-nz/news/other/china-covid-19-and-the-end-ofglobalisation-as-we-knew-it/ar-BB12s5Vp.

\section{APPENDIX: IDEAS FOR FURTHER RESEARCH STEMMING FROM THIS POINT ARTICLE}

(1) Seeking the Optimal Balance Between "Resilience" of Global Value Chains (GVC) and Overall Procurement Costs.

As Figure 1 indicates, GVC resilience can be operationalized using four variables: (1) the number of vendors for the same component or item, (2) geographical diversification of supply sources to several countries, (3) propinquity of supply sources, in terms of both geographical and political "distance", and (4) increase in inventory levels at the points of use. This lowers risk (from left to right in the dashed lines in Figure 1 exhibiting a negative slope) and increases resilience. However (1) through (4) also could represent an increase in procurement cost per unit.

- How do companies arrive at a balance between these contrary considerations? 
- How are the four measures to be operationalized? What weightage should be given to each of the variables?

- Focusing only on two variables: is the nexus between Procurement Cost Per Unit and Number of Suppliers a J-curve? If so, how does the J-curve vary depending on product or sector?

This represents a research opportunity to international business and supply chain scholars, as well as being a fundamental post-Covid-19 question for companies.

(2) Propinquity of GVCs.

It has been hypothesized that the shock of the pandemic will, to some extent, make GVCs more "regional", and that MNEs will trim excessively long-distance sources of supply. While it is unlikely that there will be large-scale reshoring (Miroudot, 2020) or substantial decoupling, as suggested by Petricevich \& Teece (2019), nevertheless some reduction in geographic coverage could occur. If so, in which sectors, regions or products?

(3) A Microfoundational Approach to Increasing GVC Resilience.

Instead of restructuring value chains, as indicated above, Kano (2018) and Verbeke (2020) suggest a behavioral or micro-foundational approach. They propose a more "relational" interaction between buyer and supplier. That is to say, a stronger and more intimate linkage between the two, accompanied by a willingness to be flexible - with mutual accommodation in the face of exogenous shocks, would be congruent with the "structural" adjustments suggested in (1) above, and would make the GVC even more resilient.

Another aspect of strengthening this relationship is technological (Schmidt \& Wagner, 2019; Kamilaris et al., 2019). Integration of buyerseller computer systems, which would give the MNE access to the vendor's servers and help it more closely monitor, in real-time, the status of their orders, reduces uncertainty and helps the MNE's own scheduling of sales and inventories (Frazzon et al., 2018). However, here again, giving such access requires trust, which is a microfoundational or behavioral issue.

(4) Reexamining the Structures and Relationships in Cross-Border Partnerships.
Interfirm relationships (and GVCs are one example) cover a spectrum from purely contractual ordering, or basic patent licensing unaccompanied by any significant interaction between licensor and licensee, all the way to forming an international joint venture where the managers, engineers, and personnel of the partners "rub shoulders" on a daily basis (Contractor \& Reuer, 2019). Much of past alliance literature, unfortunately, has used bifurcated dependent variables such as "Equity" JV (EJV) versus "Non-equity" alliances. This a distortion of reality. Actually, the majority of alliances involve some degree of interaction or relationship. For example, even in a contractual alliance, the licensor, after transferring the intellectual property rights and accompanying "know-how" (or unregistered knowledge), will continue to support and help their licensee, out of self-interest. Even more pertinently, in recent years, EJVs are covered by as detailed, or even more detailed, an agreement as are contractual alliances (Velez-Calle, 2018; Contractor \& Reuer, 2019). Research has only partially provided answers to questions such as how to construct or structure an agreement (i.e., with what clauses, depth, and length) depending on the strategic objectives (e.g., resilience, flexibility, irreversibility (Verbeke, 2020), and duration) - questions that occur in a world of increasing interorganizational relationships and supply chains.

(5) The Significance of International Royalty Payments: A Gaping Lacuna in IB Studies.

IB Scholars have long known that, instead of FDI or exporting as a means of achieving sales in foreign markets, the licensing of intellectual assets (registered property such as patents, brands, and copyrights, as well as unregistered trade secrets and tacit "know-how") results in sales by the licensee in the assigned country/territories. These licensee sales can act as a substitute strategy to FDI or trade-in terms of reaching the foreign customer. The licensee pays the licensor royalties, which are typically a percentage of the sales achieved for the licensed item. Even GVC and IJV agreements often have a licensing component, because the supplier or partner first needs to receive the legal permission to produce the MNE's designs. Moreover, payment of royalties is most often a deductible expense, reducing the licensee's corporate tax liability. 
We know from World Bank and other data that cross-border royalty payments in 2019 amounted to $\$ 397.23$ billion, and that these have grown faster, over recent decades, than the growth rate of FDI or trade. ${ }^{29}$ The $\$ 397.23$ billion number is not a sales number, it is only royalties, which are a small percentage of the licensees' achieved sales.

Astonishingly, nobody knows the strategic significance of international licensing (in terms of foreign market sales, compared with exporting or FDI affiliate sales) because we have no basis, yet, for estimating the foreign sales that result from the international licensing of intellectual assets. If we assume that the global average royalty rate is $8 \%$ of sales, by dividing 397.23 by 0.08 , we obtain an estimate of foreign licensee sales (achieved by international licensing of intellectual assets) of $\$ 4965$ billion. If, on the other hand we assume a global average royalty rate of $2 \%$, by dividing 397.23 by 0.02 , we arrive at a foreign sales estimate of $\$ 19,862$ billion (resulting from international licensing). The actual figure is likely somewhere in between. However, we just do not know, because there is no available datum about the global average royalty rate. Either estimate tells us that international licensing is a substantial substitute strategy to FDI or trade as a means of serving foreign markets.

However, there is another conundrum. Is licensing really a substitute strategy to FDI and trade? Only partially. In many cases, licensing is a complement to FDI and trade (as in GVC agreements) and not the main strategic driver. For parties related by ownership such as Parent-Subsidiary or IJV partner-JV company, the licensing portion of the agreement may only be an "add-on" clause for tax-avoidance and legal purposes. On the other hand, when the licensor and licensee are unrelated parties, then the royalty payment is based on an arms-length negotiation. Here again, astonishingly, we have no firm idea of the proportions of related party versus arms-length transactions in international business.

This investigation should be of great interest to MNEs, IB scholars, and tax authorities around the world.

\section{ABOUT THE AUTHOR}

Farok J. Contractor is Distinguished Professor of Management and Global Business at Rutgers Business School, a Fellow of the AIB, author of ten books and over 150 scholarly articles. He holds a PhD and MBA from Wharton, two engineering degrees, MS (Michigan), and BSE (Bombay), and is currently on the Board of the Academy of International Business as President-Elect (2020-2021) and President (2021-2022). Farok's research on corporate alliances, emerging markets, outsourcing and offshoring, valuation of intangible assets, the technology transfer process, licensing, and FDI has been cited more than 12,000 times. He has taught at leading schools on four continents. Previously, he was an executive with the Tata Group, a Fulbright Fellow, Unilever Fellow, and consultant for UNCTAD. Farok's blog covering International Business issues, https://globalbusiness.blog, is read by viewers worldwide.

Publisher's Note Springer Nature remains neutral with regard to jurisdictional claims in published maps and institutional affiliations.

Accepted by Alain Verbeke, Editor-in-Chief, 27 October 2020. 